\title{
To Advise and Consent: The Senate and Lower Federal Court Nominations, 1977-1998
}

\author{
Wendy L. Martinek \\ State University of New York at Binghamton \\ Mark Kemper \\ Bridgewater State College \\ Steven R. Van Winkle \\ Syracuse University
}

\begin{abstract}
Using nominations to Article III district and appeals court judgeships, we test a model of senatorial treatment of presidential nominations to the lower federal bench, looking both at outcome (whether or not a nomination culminates in confirmation) and process (the length of time it takes the Senate to process a nomination). We find evidence that nominee quality matters, as does composition of the Judiciary Committee and pending judicial nominations. Contrary to charges made in the popular press, however, neither race nor gender makes a difference for ultimate success or failure of a nomination. Duration analysis reveals that race (though not gender) does matter for district court nomination processing time. We also find presidential year and term to matter for both levels of court but the outcome of the Bork nomination to affect only appeals court nominations.
\end{abstract}

\begin{abstract}
A
rticle II $\S 2$ of the United States Constitution grants the president the authority to nominate individuals for federal judicial office, with the important proviso that such nominees must be approved by a majority vote of the Senate. This arrangement represents one of the constitutionally mandated intersections of otherwise separated powers. Given the Supreme Court's position at the apex of the federal judicial system, it is not surprising that both public and scholarly attention to the federal court appointment process has been most keen when a nomination to the nation's highest court is at issue. However, the lesser attention devoted to appeals and district court nominees belies the importance of these courts. For the vast majority of litigants in the federal judicial system, these courts effectively have the final say. This suggests that students of federal court appointments would do well to look beyond the politics of Supreme Court selection.

Since the dynamics of federal court appointments involve actors from each branch of the national government, presidential, congressional, and judicial scholars have all been interested in the federal court appointment process as an
\end{abstract}


exercise of the prerogatives reserved to each by the Constitution (Cameron, Cover, and Segal 1990; Cameron and Segal 1999; Goldman 1966; Gottschall 1983). This interest has generated detailed descriptive accounts of the process and the changes in it over time (Allison 1996; Barrow, Zuk, and Gryski 1996; Chase 1972; Goldman 1997; Hartley and Holmes 1997; McFeeley 1987). What the investigators in these studies do not offer, however, is rigorous multivariate analysis of the lower federal court confirmation process. We think that furthering our understanding of the process requires such an analysis.

In this article, we set ourselves the task of investigating more fully the Senate's treatment of presidential nominations to the lower federal courts. We do so using a newly created database consisting of all Article III district and circuit court nominations, ${ }^{1}$ from the advent of Carter's presidency through the end of Clinton's sixth year in office: $1977-1998 .^{2}$ We develop a model that integrates a variety of influences, including those related to the individual nominees, institutional factors, and political concerns. While our primary objective is to enhance the state of knowledge concerning federal judicial selection generally, we are also in a unique position to comment on two controversies that have recently dominated public discourse with regard to Congress and its confirmation responsibilities: increasing delay in the confirmation process, and the perception of differential treatment of female and minority nominees. In the next section we discuss briefly the Senate's processing of presidential nominations to the lower federal bench. In subsequent sections, we identify the elements of our explanatory model and articulate our theoretical expectations, discuss our estimation procedure and results, and conclude with some thoughts on the import of our findings.

\section{The Process of Staffing the Federal Bench}

Staffing the federal bench requires coordinated action on the part of the president and the Senate. In his recent treatment of the lower federal court selection

\footnotetext{
${ }^{1}$ Article III courts include Puerto Rico but do not include Guam, the Northern Mariana Islands, or the Virgin Islands.

${ }^{2}$ Wendy L. Martinek created the lower federal court database, utilizing the resources of the Program for Law and Judicial Politics at Michigan State University at the behest of Citizens for Independent Courts. For the analyses presented here, Mark Kemper and Steven R. Van Winkle collected extensive supplementary data. We thank Citizens, and especially its counsel and policy director Elizabeth Dahl, for providing the Congressional Research Service reports and Senate calendars used in the construction of the data set. We also appreciate the time and effort Lisa Holmes expended on a prototype database of lower federal court nominations, also at the behest of Citizens for Independent Courts. Further, we thank Betty Koed of the United States Senate Historian's Office for lending her assistance in tracking Senate recesses, and Sheldon Goldman for generously sharing his data on the gender and minority status of nominees. Finally, we thank Christopher Bonneau, Dave Clark, Kirk Randazzo, Malia Reddick, Christopher Zorn, and, especially, Harold J. Spaeth for a variety of assistance.
} 
TABLE 1

Lower Federal Court Appointment Success by Court, 1977-1998

\begin{tabular}{lrrr}
\hline & $\begin{array}{c}\text { Successful }^{\text {a }} \\
\text { Nominations }\end{array}$ & $\begin{array}{c}\text { Unsuccessful } \\
\text { Nominations }\end{array}$ & $\begin{array}{c}\text { All } \\
\text { Nominations }\end{array}$ \\
\hline Circuit courts & $232(80.3 \%)$ & $57(19.7 \%)$ & 289 \\
District courts & $887(84.8 \%)$ & $159(15.2 \%)$ & 1046 \\
Circuit and district courts & $1,119(83.8 \%)$ & $216(16.2 \%)$ & 1335 \\
\hline
\end{tabular}

\footnotetext{
${ }^{\text {a }}$ Successful nominations are those confirmed by the Senate.

${ }^{b}$ Unsuccessful nominations are those that are withdrawn by the president, rejected by the Senate or fail sine die.

Note: All nominations for Article III district and circuit court judgeships are included. Those for Guam, the Northern Mariana Islands and the Virgin Islands are not Article III judgeships and are not included.
}

Source: Citizens for Independent Courts and the authors.

process, Goldman (1997) details the mix of presidential motivations (policy, partisan, and personal) that drove the choice of nominees from Roosevelt to Reagan. Goldman's focus throughout is presidential choice. Moraski and Shipan (1999), too, focus on presidential choice, constructing spatial models to elucidate the conditions under which presidents are likely to be strategic in their choice of nominees and testing these conditions empirically. However, the bulk of the research devoted to federal court selection examines the senatorial side of the equation (e.g., Cameron, Cover, and Segal, 1990; Ruckman 1993; Segal 1987). As Guliuzza, Reagan, and Barrett (1994) have observed, most such studies have focused on outcome rather than process. Whether using the Senate (Ruckman 1993; Segal 1987) or the senator (Cameron, Cover, and Segal 1990) as the unit of analysis, the focus has been on the ultimate outcome (confirmation or rejection) instead of the process leading to it.

But success is the norm for most candidates nominated by the president at any level of the federal courts. For example, inspection of Table 1 reveals that only one in five nominations for the federal circuit courts and one in seven for the federal district courts have been unsuccessful from the advent of Carter's presidency through the end of 1998. As Allison observes: "Because few nominations that make it to the Senate Judiciary Committee hearings fail, examination of factors that affect whether or not a nominee is confirmed would not be highly informative. Speed of confirmation, however, is an indicator of ease or difficulty of confirmation" $(1996,9)$. While it appears that presidents get their way most of the time (Barrow, Zuk, and Gryski 1996; Goldman 1997), it may be that they do not get it when they want it. In addition, there is considerable variation in the length of time it takes Congress to confirm presidential nominees. As Table 2 shows, the mean number of days from nomination to confirmation during the first six years of the Clinton administration is more than 
TABLE 2

Mean Number of Days from Nomination to Confirmation, 1977-1998

\begin{tabular}{lccccc}
\hline & Carter & Reagan & Bush & Clinton & Carter-Clinton \\
\hline Circuit courts & 50.9 & 43.4 & 60.0 & 100.3 & 60.5 \\
& $(57)$ & $(83)$ & $(42)$ & $(50)$ & $(232)$ \\
District courts & 52.7 & 39.7 & 61.5 & 76.4 & 56.5 \\
& $(201)$ & $(290)$ & $(148)$ & $(248)$ & $(887)$ \\
Circuit and district courts & 52.3 & 40.5 & 61.2 & 80.4 & 57.4 \\
& $(258)$ & $(373)$ & $(190)$ & $(298)$ & $(1,119)$ \\
\hline
\end{tabular}

Note: Days from nomination to confirmation corrected for Senate recess days. Numbers in parentheses indicate number of nominations.

Source: Citizens for Independent Courts and the authors.

double that of the Reagan administration, while the Bush average represents a $40 \%$ increase over the Carter years. Accordingly, we first examine the likelihood of confirmation and then investigate the length of time between nomination and confirmation - confirmation duration. We next turn our attention to specifying those elements we think particularly important for understanding the treatment on Capitol Hill of presidential nominations to the lower federal courts.

\section{Explaining Outcome and Delay}

Goldman has argued that the dominant goal for presidents in lower federal court selection prior to Reagan was the pursuit of a partisan agenda, that is, shoring up "political support for the president or the party" (1997, 3). However, to a much greater degree than his predecessors, Reagan discerned the importance of those staffing the federal bench for the advancement of his policy goals. Other scholars have also detailed extensive changes, including centralization, in the judicial recruitment process begun under the Carter and Reagan administrations (Allison 1996; Hartley and Holmes 1997; Slotnick 1988). This centralization has been attributed to the emerging sense of the importance of lower federal court appointments for presidential legacies, a sentiment of which senators and presidents alike partake and that has continued beyond the Carter and Reagan administrations (Hartley and Holmes 1997, 277).

A concurrent development has been an increased concern with increasing the racial and gender diversification of the federal bench. President Carter was especially in favor of doing so (Goldman 1997; Allison 1996), and Presidents Bush and Clinton also pursued this goal to varying degrees (Goldman 1993, 1995). In conjunction with the increased attention presidents have paid to the gender and racial identity of their nominees, some commentators have argued 
that there has been greater scrutiny of such non-traditional nominees on the part of the Senate. ${ }^{3}$ With these two developments in mind, we have constructed a comprehensive model of senatorial confirmation politics. We group our explanations into three broad categories: (1) nominee characteristics, (2) institutional features, and (3) political factors. As will become clear in the following discussion, not all variables fall wholly into any single category. Nevertheless, for expository purposes we place our explanatory variables into the most relevant category in the discussion that follows.

\section{Nominee Characteristics}

With regard to the characteristics of nominees, we focus on three that are of particular interest: American Bar Association (ABA) rating, race, and gender.

Actors involved in the nomination and confirmation of judges to the federal bench make reference to nominee qualification as a criterion for evaluating potential judges, in rhetoric if not always in fact. ${ }^{4}$ Given the ambiguous nature of "candidate quality," there is obviously more than one way of defining the concept. However, one measure, the American Bar Association's rating of nominees, has been relied upon by both the president and the Senate (Goldman 1997) and, so, is appropriate for present purposes. ${ }^{5}$

There is also extant empirical evidence supportive of the link between ABA rating and senatorial treatment. Both Allison (1996) and Holmes and Hartley (1998) find a negative bivariate relationship between higher ABA ratings and the length of time between referral and confirmation for lower federal court nominations. Even if a president was not terribly concerned with the quality of those nominated to the bench, that president would have reason to choose those nominees with favorable ABA ratings. Higher ABA ratings disadvantage presidential opponents in the Senate, since the president can claim his nominations enhance the quality of the federal bench while characterizing those opposed to

\footnotetext{
${ }^{3}$ Herman Schwartz, "The GOP's Judicial Delays and the Costs to Minorities," The Los Angeles Times, 15 February 1998.

${ }^{4}$ Of course, Senator Roman Hruska's attempt to elevate G. Harrold Carswell to the Supreme Court belies this contention. Responding to allegations of Carswell's mediocrity, Hruska pleaded that "even if he is mediocre there are a lot of mediocre judges and people and lawyers. They are entitled to a little representation, aren't they, and a little chance? We can't have all Brandeises, Cardozos, Frankfurters, and stuff like that there" (quoted in Abraham 1992, 16-17).

${ }^{5}$ Prior to 1989 there were four basic ratings given by the ABA: not qualified, qualified, well qualified, exceptionally well qualified. The exceptionally well qualified rating is no longer in use. Nominees can also receive split ratings, such as qualified/not qualified, well qualified/exceptionally well qualified. To reflect the nuance of split ratings, in the analysis that follows, we use a six-point scale: 1 = not qualified; 2 = qualified/not qualified; 3 = qualified; 4 = qualified/well qualified; 5 = well qualified/qualified; and $6=$ well qualified or above. Not only does this scale account for split ratings, it also takes into account the discontinuation of the exceptionally well qualified rating by treating all ratings of well qualified or above as comparable.
} 
his nominees as merely interjecting partisan politics into the process, as Clinton did quite often. ${ }^{6}$ This suggests our first hypothesis:

Increasing candidate quality, as measured via ABA ratings, will make confirmation of a nominee more likely and decrease the length of time between nomination and confirmation.

There are other nominee characteristics beyond candidate quality that have the potential for influencing the process. Ronnie L. White, the first black judge to serve on Missouri's state supreme court, recently was rejected by the Senate on party lines. Senators John Ashcroft (R-MO) and Orrin Hatch (R-UT) initially opposed White's nomination, claiming White had been insufficiently supportive of the death penalty. White's supporters, however, decried the vote as racially motivated. President Clinton characterized the vote as providing "strong evidence for those who believe that the Senate treats minority and women judicial nominees unequally." 7 The executive director of the Leadership Conference on Civil Rights was equally vehement in his denunciation:

The Senate Republican leadership is clearly pursuing a scorched-earth policy on judicial nominations, and Ronnie White is the first casualty. The veneer of fairness that Republicans said they had is now clearly destroyed — for all candidates, but particularly for African Americans and Hispanics. ${ }^{8}$

Controversy was similarly fierce over the nomination of Richard A. Paez, a federal district court judge, to the $9^{\text {th }}$ Circuit Court of Appeals. Though Paez ultimately secured confirmation with a 59 to 39 vote in March 2000, he was initially nominated in January 1996, giving him the dubious distinction of having experienced the longest wait of any nominee. ${ }^{9}$ The bivariate relationship between the race of the nominee and the length of time between nomination and confirmation provides prima facie support for the contention of differential treatment of minority and nonminority nominees, as can be seen in Figure $1 .{ }^{10}$ Accordingly, we hypothesize that

The nomination of a member of an ethnic or racial minority will be less likely to receive favorable treatment in the Senate with respect to both delay in, and likelihood of, confirmation.

${ }^{6}$ Nancy Mathis, "Clinton Defends Judiciary Over Politics," The Houston Chronicle, 28 September 1997, sec. A.

${ }^{7}$ Charles Babington and Joan Biskupic, "Senate Rejects Judicial Nominee," The Washington Post, 6 October 1999, sec. A.

${ }^{8}$ Quoted in Charles Babington and Joan Biskupic, "Senate Rejects Judicial Nominee," The Washington Post, 6 October 1999, sec. A.

${ }^{9}$ Helen Dewar. "Embattled Court Nominees Are Confirmed," The Washington Post, 10 March 2000 , sec. A.

${ }^{10}$ There were 121 African American nominees, 64 Hispanic nominees, 1 Native American nominee, and 11 Asian American nominees, for a total of 197 minority nominees. Since some of these minority nominees failed to secure confirmation upon their initial nomination and were renominated, the 197 minority nominees account for 213 minority nominations altogether. 
FIGURE 1

Minority Status and Confirmation Duration

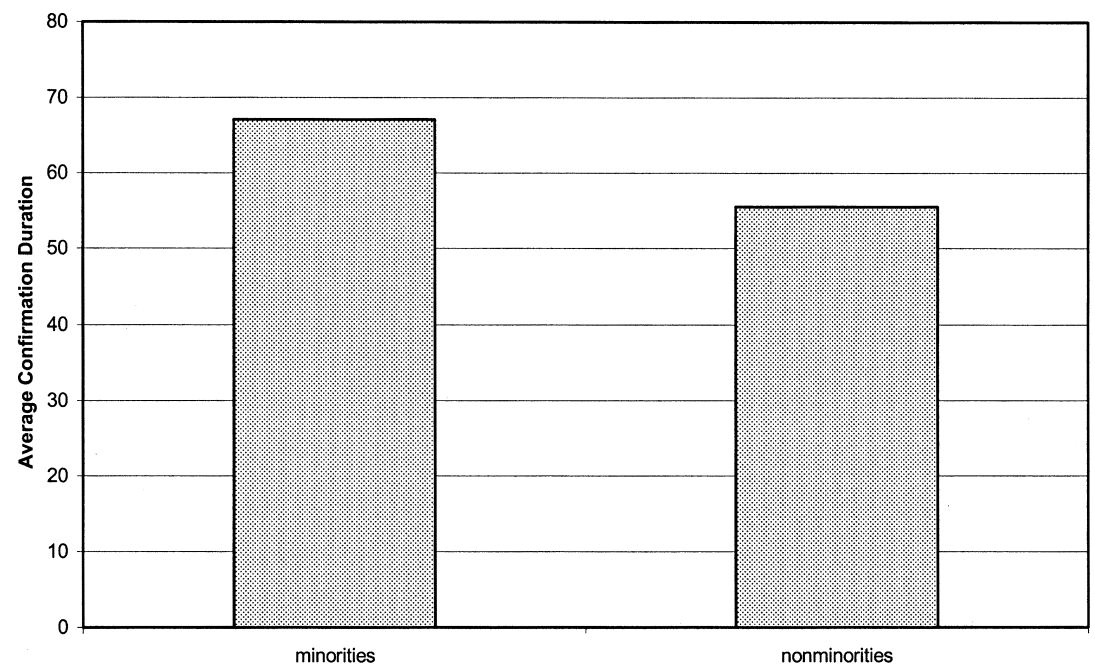

While presidents have expressed concern with the lack of female jurists on the federal bench and evidenced greater numbers of confirmed female jurists than has historically been the case, Congress has not been insulated from charges that the nominations of women, like the nominations of minorities, are more frequently subjected to dilatory tactics. For example, Michigan Court of Appeals judge Helene White was nominated for a judgeship on the $6^{\text {th }}$ Circuit Court of Appeals but has been delayed in the Senate Judiciary Committee for over three years. ${ }^{11}$ Further, California attorney Marsha S. Berzon recently secured confirmation to the $9^{\text {th }}$ Circuit only after a controversial nomination batthe that brought Vice President Gore to the Senate on standby, in the event that his vote was needed to break a tie vote on her confirmation. ${ }^{12}$ Looking at the bivariate relationship between gender and the average number of days between nomination and confirmation lends credence to the claim of differential treatment based on gender, as can be seen in Figure 2; nominations of females took over 15 days longer than nominations of males, on average, between 1977 and 1998. This leads to our third hypothesis:

\footnotetext{
${ }^{11}$ Dee-Ann Durbin, "Abraham Criticized for Stalling Judicial Nominations," The Lansing State Journal, 9 November 1999, sec. B.

${ }^{12}$ Helen Dewar, "Embattled Court Nominees Are Confirmed," The Washington Post, 10 March 2000 , sec. A.
} 
FIGURE 2

Gender and Confirmation Duration

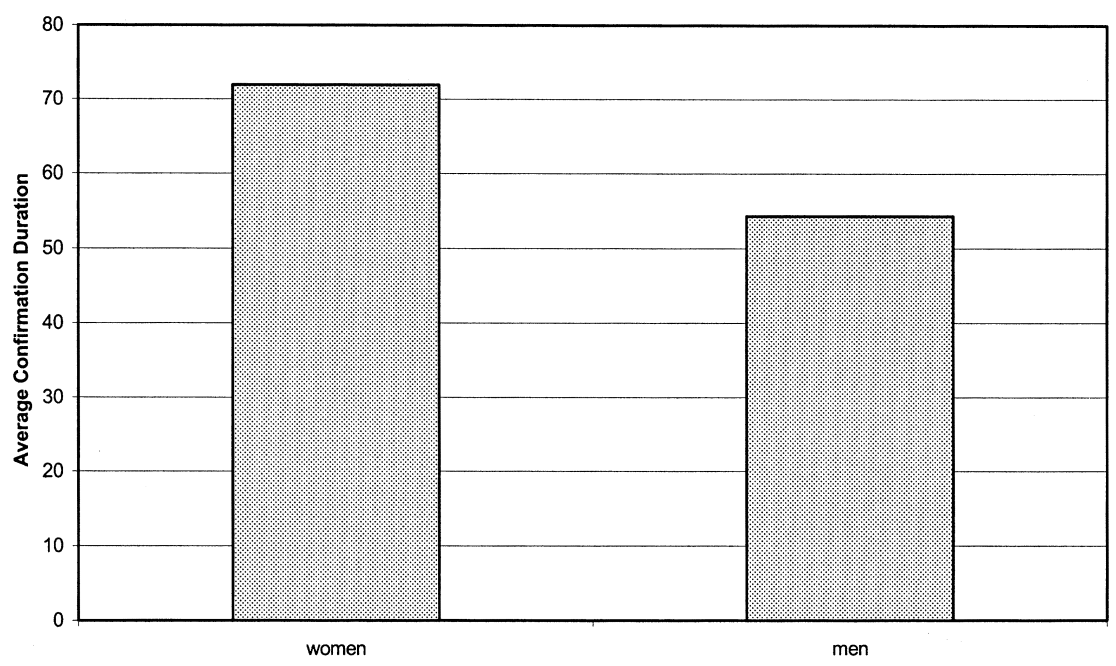

The nomination of a female nominee will be less likely to receive favorable treatment in the Senate with respect both to delay in, and likelihood of, confirmation.

\section{Institutional Variables}

There are also variables pertaining to the presidency and the Senate at the time of nomination requiring consideration, including the year of the presidential term in which the nominating president is serving, the term in which the nominating president is serving, and the number of lower federal court nominations pending in the Senate at the time of nomination.

A president serving in his first year of office may well benefit from a honeymoon period in which Congress is more positively disposed toward a president's initiatives, including a president's nominations to the bench (Allison 1996; Bond and Fleisher 1990; Holmes and Hartley 1998). As the presidential term progresses and the honeymoon effect wanes, however, presidential nominees are likely to experience less favorable treatment. Our fourth hypothesis, then, is:

Favorable senatorial treatment (both in likelihood of confirmation and speed of confirmation) will be less likely as a president's term of office progresses.

A separate but related hypothesis concerns which term of office a president is serving when making a nomination. Two of the four presidents in our analysis 
secured second terms in office. The Senate may be less eager to confirm the appointments of second-term presidents as opposed to first-term presidents. Senators know that a second-term president's time in office is limited and thus should be less enthusiastic about confirming his judicial nominees, while uncertainty exists regarding the sunset of tenure for a first-term president. Further, senators are more likely to feel that a second-term president has already had sufficient opportunity to put his imprimatur on the federal bench. This forms the crux of our fifth hypothesis:

The nominations of second-term presidents will receive less favorable treatment by the Senate than the nominations of first-term presidents.

That is, they will be less likely to be confirmed in the first place, and those who do secure confirmation will experience longer processing time in the Senate.

In addition to these presidentially centered institutional characteristics, there is an important variable pertaining to the Senate that must be taken into account. The number of judicial nominations making their way through the senatorial process at any one time varies, but the amount of time available to process such nominations is not elastic. This suggests that the number of lower federal court nominations pending in the Senate when a nomination is made is likely to impact the processing of that nomination. When there are numerous nominations pending, the Senate and the Judiciary Committee may find it difficult to process them expeditiously. This suggests an additional hypothesis:

The greater the number of pending lower federal court nominations, the less likely it is for a nomination to end in confirmation; and by extension, those that do result in confirmation are apt to take longer.

\section{Political Factors}

Given the overwhelming anecdotal evidence and support in the descriptive literature, we would be remiss if we suggested that nominee-specific characteristics and institutional features were sufficient to explain the Senate's treatment of presidential nominations for the lower federal courts. The confirmation process is political in nature, and, therefore, political factors will undoubtedly affect the Senate's treatment of the president's nominations to the lower federal bench. We consider specifically the likely effects of the partisan composition of the Senate Judiciary Committee, midterm elections as conditioned by unified government, the nomination of Robert Bork, presidential approval ratings, and the timing of nominations.

The Senate Judiciary Committee plays a pivotal role in the confirmation process. This committee is responsible for holding hearings on judicial nominees, and Committee members are the senators most intimately involved in the processing of these nominations. The disapproval of the Senate Judiciary Committee is a formidable obstacle for any nomination to hurdle. Delay and perhaps outright failure are increasingly more likely as the composition of the Judiciary 
Committee becomes less favorably predisposed to the president's policy agenda. Thus, we hypothesize the following:

The greater the percentage of the Judiciary Committee membership that is not of the president's party, the less likely confirmation is and the greater the expected delay in the Senate for those nominations that do result in confirmation.

More generally, the president's party typically loses seats in the Senate during midterm elections, a fact of which senators are quite aware. In light of this, we hypothesize the following:

In anticipation of a possible change in partisan control of the Senate, when a nomination is made in a midterm election year under conditions of unified government the Senate should afford presidential nominations to the lower federal bench more favorable consideration both in the likelihood of confirmation and the length of time necessary to reach that result.

The high-profile, failed nomination of Robert Bork is an additional factor that has significantly enhanced the politicization of the process. Both scholars and pundits have debated and analyzed the failed nomination of Robert Bork (e.g., Bronner 1989; Caldeira and Wright 1998). An inspection of Figure 3, which depicts the average number of days from nomination to confirmation by congressional term, does indeed suggest a structural break corresponding to

FIGURE 3

Congressional Term and Confirmation Duration

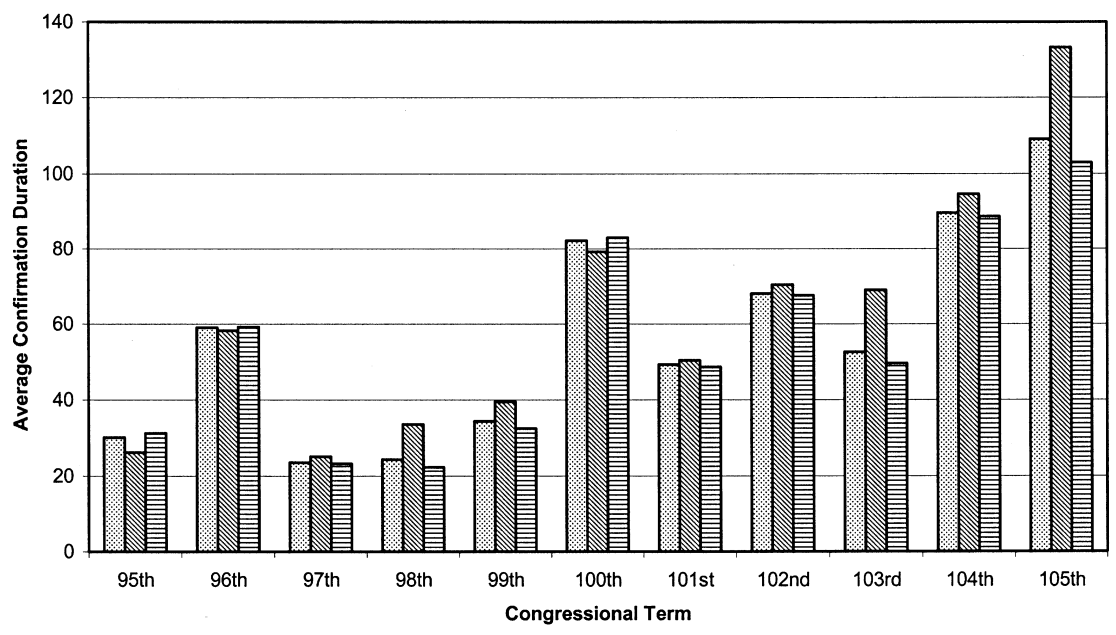

图Appeals and District Courts $\mathbb{N}$ Appeal Courts 目District Courts 
the failed Bork nomination: the mean number of days between nomination and confirmation increases commencing with the $100^{\text {th }}$ Congress. Accordingly, we hypothesize the following:

Nominations made after the failed Bork nomination are less likely to receive favorable treatment by the Senate than those made prior to the events of the Bork nomination.

The penultimate explanatory factor we consider is presidential approval. Presidential approval taps into the resources at the president's disposal to achieve his desired goals, including securing confirmation for his chosen nominees to the lower federal bench as a means of pursuing policy goals (or, at the very least, protecting policy agenda advances secured in the legislative arena). Hence,

Nominations will receive more favorable treatment when the president enjoys higher levels of public approval.

Our final prediction has to do with the timing of presidential nominations. One way or the other, at the end of a congressional term a nomination either succeeds or fails. In terms of ultimate outcome, there may well be a relationship between when a nomination is submitted and its likelihood of confirmation. Holmes and Hartley (1998) suggest that nominations made at the end of a Senate session may either be hurried through the process to beat the deadline imposed by the adjournment of the Senate or, alternatively, intentionally delayed. Though they find little support for either thesis, their reasoning can be extended to consider the potential effects of timing more generally. Presidential nominations made earlier in a congressional term may fare worse at the hands of the Senate as partisan opponents have more time to gather and disseminate unflattering information regarding the nominee. Conversely, submitting nominations later in a congressional term affords less opportunity for opponents to uncover such information. Accordingly, we hypothesize the following:

Nominations made earlier in a congressional session will experience less favorable treatment in the Senate, meaning a smaller likelihood of confirmation and longer processing times.

For the reader's convenience, our hypotheses are summarized in Table 3, and summary statistics for each of the independent variables appear in Table 4. The coding of these variables is reported in detail in the Appendix.

\section{Data and Estimation}

The data for this project consist of presidential nominations for Article III circuit and district court vacancies submitted to the Senate from the beginning of 1977 through the end of $1998 .^{13}$ The total number of nominations in this

\footnotetext{
${ }^{13}$ As noted earlier, these include those for Puerto Rico but not those for Guam, the Northern Mariana Islands, or the Virgin Islands.
} 
TABLE 3

Summary of Hypotheses

\begin{tabular}{|c|c|c|c|}
\hline & Variable & $\begin{array}{l}\text { Hypothesized } \\
\text { Effect on } \\
\text { Likelihood of } \\
\text { Confirmation }\end{array}$ & $\begin{array}{l}\text { Hypothesized } \\
\text { Relationship to } \\
\text { Length of } \\
\text { Confirmation } \\
\text { Duration }\end{array}$ \\
\hline \multicolumn{4}{|c|}{ NOMINEE } \\
\hline & ABA rating & + & - \\
\hline & minority nominee & - & + \\
\hline & female nominee & - & + \\
\hline \multicolumn{4}{|c|}{ INSTITUTION } \\
\hline \multirow[t]{2}{*}{ President } & presidential year & - & + \\
\hline & $2^{\text {nd }}$ term president & - & + \\
\hline Senate & $\begin{array}{l}\text { percentage of Judiciary } \\
\text { Committee members of } \\
\text { non-presidential party }\end{array}$ & - & + \\
\hline Court & $\begin{array}{l}\text { number of judicial } \\
\text { nominations pending }\end{array}$ & - & + \\
\hline \multicolumn{4}{|c|}{ POLITICS } \\
\hline & $\begin{array}{l}\text { midterm election under } \\
\text { unified government }\end{array}$ & + & - \\
\hline & post-Bork nomination & - & + \\
\hline & presidential approval & + & - \\
\hline & $\begin{array}{l}\text { month of congressional } \\
\text { term nomination made }\end{array}$ & + & - \\
\hline
\end{tabular}

period was 1,335 . We excluded 29 nominations due to missing data. This resulted in a total of 1,306 nominations for analysis. Not all of these 1,306 nominations are independent of one another. Since we treat each nomination separately, a nominee who fails to secure confirmation in one congressional term and is renominated by the president appears in the data set once for each nomination. Of the 1,306 nominations we have, 85 involve the renomination of the same individual for the same vacancy. While at first blush it may appear preferable to combine these separate nominations into one observation, there are practical reasons that make this difficult, not the least of which is determining the appropriate way to measure the time between nomination and confirmation. Considering the time from nomination to ultimate confirmation ignores the fact that if a nomination expires sine die, the Senate has no nomination properly before it to process until the president makes the renomination in the following congressional term. Subtracting the number of days that elapse between the Senate's adjournment and the date of renomination by the president creates its 
TABLE 4

\section{Summary Statistics}

\begin{tabular}{|c|c|c|c|c|c|c|}
\hline & Variable & Mean & Median & St. Dev. & Min. & Max. \\
\hline \multicolumn{7}{|l|}{ NOMINEE } \\
\hline & ABA rating & 4.50 & 5.00 & 1.54 & 1 & 6 \\
\hline & minority nominee & 0.16 & 0.00 & 0.37 & 0 & 1 \\
\hline & female nominee & 0.17 & 0.00 & 0.38 & 0 & 1 \\
\hline \multicolumn{7}{|c|}{ INSTITUTION } \\
\hline \multirow[t]{2}{*}{ President } & presidential year & 2.47 & 3.00 & 1.05 & 1 & 4 \\
\hline & $2^{\text {nd }}$ term president & 0.28 & 0.00 & 0.45 & 0 & 1 \\
\hline Senate & $\begin{array}{l}\text { percentage of Judiciary } \\
\text { Committee members of } \\
\text { non-presidential party }\end{array}$ & 48 & 44 & 7.00 & 35 & 57 \\
\hline Court & $\begin{array}{l}\text { number of judicial } \\
\text { nominations pending }\end{array}$ & 24.77 & 22.00 & 16.62 & 0 & 145 \\
\hline \multicolumn{7}{|l|}{ POLITICS } \\
\hline & $\begin{array}{l}\text { midterm election } \\
\text { under unified } \\
\text { government }\end{array}$ & 0.16 & 0.00 & 0.37 & 0 & 1 \\
\hline & post-Bork nomination & 0.49 & 0.00 & 0.50 & 0 & 1 \\
\hline & presidential approval & 51.44 & 51.00 & 11.63 & 29 & 87 \\
\hline & $\begin{array}{l}\text { month of congressional } \\
\text { term nomination made }\end{array}$ & 11.31 & 11.00 & 5.80 & 1 & 24 \\
\hline
\end{tabular}

Note: Original $\mathrm{N}=1,335$; final $\mathrm{N}=1,306$ due to missing data.

own difficulty; we now have one nomination that has time-varying covariates since variables such as presidential year and divided government will likely have changed. Reconfiguring the data set to allow for duration analysis with such time-varying covariates is prohibitive, however, given the number of nominations during the period of study. To take into account the fact that some nominations are really renominations, we include a control variable coded as 1 if the nominee was previously nominated for the same position but not confirmed, and as 0 otherwise.

Before proceeding to the analysis, readers should make note of one additional item. Differences in their respective dockets ensure that the circuit courts have a greater potential impact on policy than do the district courts. This suggests a basis for differential senatorial treatment of appeals court and district court nominations. As Allison has stated:

Having a wider jurisdiction than the district courts and positioned above the district courts in the judicial hierarchy, circuit court judges hold a more powerful position than district court judges. As a result, circuit court nominees are likely to be subjected to greater scrutiny during the confirmation process $(1996,9)$. 
To account for the difference in the potential policy consequences of district and circuit courts, we treat district and circuit court nominations separately in the analyses that follow.

\section{Outcome}

We begin our analysis by evaluating the explanatory value of our model for outcome. In this first stage of analysis, the dependent variable is whether or not a presidential nomination ends with Senate confirmation. The dichotomous nature of the dependent variable makes logit an appropriate estimation technique. ${ }^{14}$ The results of this estimation, including marginal effects, ${ }^{15}$ are reported in Table $5 .^{16}$

Of the nominee characteristics considered, only the ABA rating makes a difference in the ultimate success or failure of a nomination. Contrary to conventional wisdom, neither the race nor the gender of the nominee makes a difference. The only other variable that affects the likelihood of confirmation for appeals court nominations is presidential year. There does, indeed, appear to be a honeymoon effect, with presidents less likely to secure confirmation of their nominees as their term of office advances. While presidential year has no effect on nomination outcome for district court vacancies, a number of other factors do. Specifically, renominations of individuals who have failed to secure confirmation are less likely to be confirmed. For nominations with an a priori probability of being confirmed of 0.5 , the renomination of an individual for the same vacancy is decreased by $57 \%$. Further, contrary to expectations, second-term presidents are more rather than less likely to see their district court nominations result in confirmation. In fact, presidential term has the second greatest marginal effect for district court nominations after the renomination variable, with the likelihood of confirmation increasing $27 \%$ over a nomination with an a priori probability of confirmation of 0.5 . Perhaps achieving a second term in office serves to enhance the perceived legitimacy of that officeholder in the Senate. Midterm elections when the presidency and the Senate are controlled by the same party likewise enhance the likelihood of

\footnotetext{
${ }^{14}$ Given the widespread use of logit in the political science literature and the many fine treatments of this estimation procedure (e.g., Aldrich and Nelson 1984), we do not detail the specifics of logit estimation here.

${ }^{15}$ Marginal effects are calculated on the basis of a nomination with an a priori probability of ending in confirmation of 0.50 , ceteris paribus.

${ }^{16}$ We tested for potential unit effects of congressional term by regressing the residuals from the logit model on a set of dummy variables representing each of the congressional terms in our study, with the $95^{\text {th }}$ Congress used as the excluded category. The results of this diagnostic indicated no need to control for congressional term. However, the results of a similar diagnostic for presidential administration did indicate the presence of unit effects for the Reagan administration for both district and circuit court nominations and for the Clinton administration for district court nominations. Accordingly, we included relevant dummy variables for them. Further, inspection of the relevant correlation matrix revealed no indication of multicollinearity.
} 
TABLE 5

\section{Logit Estimation of Lower Federal Court Confirmation, 1977-1998}

\begin{tabular}{|c|c|c|c|c|}
\hline \multirow[b]{2}{*}{ Variable } & \multicolumn{2}{|c|}{ Appeals Courts } & \multicolumn{2}{|c|}{ District Courts } \\
\hline & $\begin{array}{l}\text { Parameter } \\
\text { Estimate }\end{array}$ & $\begin{array}{l}\text { Marginal } \\
\text { Effect }^{\mathrm{a}}\end{array}$ & $\begin{array}{l}\text { Parameter } \\
\text { Estimate }\end{array}$ & $\begin{array}{l}\text { Marginal } \\
\text { Effect }^{\mathrm{a}}\end{array}$ \\
\hline $\mathrm{ABA}$ rating & $\begin{array}{l}0.327 * * \\
(0.140)\end{array}$ & 0.08 & $\begin{array}{r}0.203 * \\
(0.069)\end{array}$ & 0.05 \\
\hline Minority nominee & $\begin{array}{l}-0.505 \\
(0.505)\end{array}$ & - & $\begin{array}{c}-0.017 \\
(0.283)\end{array}$ & - \\
\hline Female nominee & $\begin{array}{r}-0.019 \\
(0.512)\end{array}$ & - & $\begin{array}{c}0.133 \\
(0.276)\end{array}$ & - \\
\hline Renomination & $\begin{array}{c}0.020 \\
(0.869)\end{array}$ & - & $\begin{array}{c}-2.297^{*} \\
(0.485)\end{array}$ & -0.57 \\
\hline Presidential year & $\begin{array}{r}-0.924^{*} \\
(0.293)\end{array}$ & -0.23 & $\begin{array}{r}-0.042 \\
(0.137)\end{array}$ & - \\
\hline $2^{\text {nd }}$ term president & $\begin{array}{r}-0.819 \\
(0.547)\end{array}$ & - & $\begin{array}{r}1.071^{*} \\
(0.357)\end{array}$ & 0.27 \\
\hline $\begin{array}{l}\text { Percentage of Judiciary Committee } \\
\text { members of non-presidential party }\end{array}$ & $\begin{array}{r}-0.080 \\
(0.056)\end{array}$ & - & $\begin{array}{l}-0.107 * * \\
(0.033)\end{array}$ & \\
\hline Number of pending judicial nominations & $\begin{array}{c}-0.007 \\
(0.014)\end{array}$ & - & $\begin{array}{r}-0.052^{*} \\
(0.013)\end{array}$ & -0.01 \\
\hline $\begin{array}{l}\text { Midterm election under unified } \\
\text { government }\end{array}$ & $\begin{array}{l}0.398 \\
(0.771)\end{array}$ & - & $\begin{array}{r}0.841^{*} \\
(0.402)\end{array}$ & 0.21 \\
\hline Post-Bork nomination & $\begin{array}{r}-0.427 \\
(0.895)\end{array}$ & - & $\begin{array}{c}0.056 \\
(0.500)\end{array}$ & - \\
\hline Presidential approval & $\begin{array}{c}-0.017 \\
(0.029)\end{array}$ & - & $\begin{array}{c}-0.007 \\
(0.014)\end{array}$ & - \\
\hline Month & $\begin{array}{r}-0.044 \\
(0.044)\end{array}$ & - & $\begin{array}{r}-0.147^{*} \\
(0.026)\end{array}$ & -0.04 \\
\hline \multicolumn{5}{|l|}{ Unit effects } \\
\hline Reagan & - & - & $\begin{array}{r}-2.145^{*} \\
(0.522)\end{array}$ & -0.54 \\
\hline Clinton & $\begin{array}{c}-1.605^{*} \\
(0.603)\end{array}$ & -0.40 & $\begin{array}{r}-1.225^{*} \\
(0.364)\end{array}$ & -0.31 \\
\hline Constant & \multicolumn{2}{|c|}{$\begin{array}{c}9.277 * \\
(3.412)\end{array}$} & \multicolumn{2}{|c|}{$\begin{array}{l}11.017^{*} \\
(1.859)\end{array}$} \\
\hline $\mathrm{N}$ & \multicolumn{2}{|c|}{280} & \multicolumn{2}{|c|}{1026} \\
\hline LL & \multicolumn{2}{|c|}{-94.183} & \multicolumn{2}{|c|}{-311.139} \\
\hline$\%$ modal category & \multicolumn{2}{|c|}{82.86} & \multicolumn{2}{|c|}{86.45} \\
\hline$\%$ correctly predicted & \multicolumn{2}{|c|}{85.36} & \multicolumn{2}{|c|}{88.11} \\
\hline $\mathrm{PRE}^{\mathrm{b}}$ & \multicolumn{2}{|c|}{14.59} & \multicolumn{2}{|c|}{12.25} \\
\hline
\end{tabular}

${ }^{*} p<0.01,{ }^{* *} p<0.05$

Note: Numbers in parentheses are robust standard errors.

${ }^{a}$ Marginal effects represent the percentage change in the predicted probability of a nomination terminating in confirmation for a nomination with an a priori probability of confirmation of 0.50 .

${ }^{\mathrm{b}} \mathrm{PRE}=$ Proportional Reduction in Error $=100 \times[(\%$ correctly predicted $-\%$ in modal category $) /(100 \%-\%$ in modal category $)]$. 
confirmation. In contrast, as the percentage of non-presidential party Judiciary Committee members and the number of pending judicial nominations increase, the likelihood of confirmation decreases. Finally, the effect of the month of the congressional term in which a nomination is made is both negative and statistically significant. This implies that presidents are disadvantaged in ultimate judicial outcome by delaying submission of judicial nominees until later in a congressional term.

Given the high rate of confirmation for both appeals court and district court nominations, it is not surprising to find that the models offer little improvement over merely guessing that a nomination will end in confirmation. The proportional reduction in error does not exceed $15 \%$ in either model. What is of interest, though, is that even when taking into account a host of other factors, and specifically controlling for nominee quality as measured by ABA rating, neither race nor gender matters in the ultimate success or failure of a nomination.

\section{Process}

We believe the more interesting question is what accounts for how long the Senate takes to act on presidential nominations to the lower federal courts. In this stage of our analysis, we focus on the process rather than the outcome. Duration analysis is particularly well suited for our purposes. ${ }^{17}$ Essentially, we have a model of competing risks: confirmation, withdrawal of the nomination, return of the nomination to the president. ${ }^{18}$ The advantage of applying a duration estimation technique comes from being able to use information on the independent variables for cases that do not experience the event despite the fact that the event does not occur. ${ }^{19}$ Such cases are censored. In effect, we recapture information that would be lost if, for example, OLS estimation were used. The event we are interested in is confirmation, so we treat all events other than confirmation as censored. ${ }^{20}$

${ }^{17}$ If final action always resulted in confirmation, a simple OLS estimation would be appropriate. However, final action comes in more than one guise, requiring special consideration in the estimation of any explanatory models.

${ }^{18}$ A nomination is returned to the president most often due to the Senate's failure to act and the nomination being returned to the president sine die. Typically, the president then must renominate that individual in the following Senate term.

${ }^{19}$ The key characteristic to note is that each event is mutually exclusive. That is, when one event occurs (e.g., confirmation), the nominee is no longer at risk of experiencing another event (e.g., returned sine die). In light of this, we can estimate the likelihood of an event in the risk set, treating the other events in the risk set as censored (Blossfeld, Hamerle, and Mayer 1989, 75-76; BoxSteffensmeier and Jones 1997).

${ }^{20}$ Estimating the hazard rate for events other than confirmation is substantively uninteresting since in almost every case that event consists of the nomination expiring at the end of the congressional session. Therefore, the length of time from nomination by the president to failure of the nomination is merely a function of when the nomination was made relative to the end of the congressional term in which the nomination was made. 
We have chosen the Weibull model for estimation. ${ }^{21}$ The hazard function for the Weibull model is as follows:

$$
h(t)=h p(h t)^{p-1}
$$

The model is parameterized as:

$$
h(t)=\exp \left(-\beta^{\prime} X+p \ln t\right)
$$

with $\beta^{\prime} X$ representing the effect of the independent variables on the risk of experiencing an event (the hazard rate) and $p$ representing the shape parameter indicating duration dependence. Given our expectation of positive duration dependence, we anticipate $p$ will be greater than $1 .{ }^{22}$

The underlying dependent variable is the hazard rate; the hazard of confirmation occurring. Parameter estimates indicate the effect of the variable on the hazard rate, with positive estimates increasing the hazard rate (i.e., decreasing the expected duration) and negative estimates decreasing the hazard rate (i.e., increasing the expected duration). The hazard ratios, on the other hand, indicate the effect of a one-unit change in the dependent variable on the hazard ratio, ceteris paribus. ${ }^{23}$ The results of our Weibull estimation of confirmation duration are reported in Table 6 . The pattern of effects is quite interesting. ${ }^{24}$

The shape parameter $(p)$ confirms our initial assumption of positive duration dependence: the longer a nomination goes without resulting in confirmation, the more likely confirmation will occur. While seemingly counterintuitive, this result comports with our general understanding of the process as we have

${ }^{21}$ While the Cox Proportional Hazards model is less restrictive in that it does not make any assumptions regarding the hazard rate (other than proportionality of the rate over values of the independent variables), it is less desirable as a means of estimation when there are multiple ties, as is the case here. Box-Steffensmeier and Jones (1997) provide a particularly useful and accessible treatment of the Weibull model and its estimation. The Weibull model has the advantage of allowing us to incorporate time dependence, and an empirical analysis of the hazard rate gives us reason to believe that the longer a nomination has gone without final action, the more likely it is for confirmation to take place; that is, the evidence suggests positive duration dependence. Our evaluation was based on analysis of Kaplan-Meier plots.

${ }^{22}$ If $p<1$ then we would have negative duration dependence; that is, the longer a nomination goes without confirmation the less likely confirmation is to occur. If $p=1$ then we would have no duration dependence; that is, the likelihood of confirmation is unrelated to how long a nomination has gone without final Senate action.

${ }^{23}$ Hazard ratios greater than one indicate a positive effect on the hazard rate while hazard ratios less than one indicate a negative effect on the hazard rate. In the case of a dummy variable, the hazard ratio represents the effect on the hazard ratio when the dummy variable equals one (e.g., nomination of a minority, nomination by a second-term president).

${ }^{24}$ Regressing the deviance residuals from our full model of confirmation duration on presidential dummies, with Carter as the excluded category, suggested a difference for Reagan nominations to the district courts not fully captured by the set of explanatory variables included in our model. The sign of the Reagan dummy indicates that all else being equal, a nomination made by Reagan has a higher hazard rate and a shorter confirmation duration. Further, inspection of the relevant correlation matrix revealed no indication of multicollinearity. 
TABLE 6

Weibull Estimation of Lower Federal Court Confirmation Duration, 1977-1998

\begin{tabular}{|c|c|c|c|c|}
\hline \multirow[b]{2}{*}{ Variable } & \multicolumn{2}{|c|}{ Appeals Courts } & \multicolumn{2}{|c|}{ District Courts } \\
\hline & $\begin{array}{l}\text { Hazard } \\
\text { Ratio }\end{array}$ & $\begin{array}{l}\text { Parameter } \\
\text { Estimate }\end{array}$ & $\begin{array}{l}\text { Hazard } \\
\text { Ratio }\end{array}$ & $\begin{array}{l}\text { Parameter } \\
\text { Estimate }\end{array}$ \\
\hline $\mathrm{ABA}$ rating & $\begin{array}{l}1.157^{*} \\
(0.061)\end{array}$ & $\begin{array}{c}0.146^{*} \\
(0.053)\end{array}$ & $\begin{array}{l}1.115^{*} \\
(0.034)\end{array}$ & $\begin{array}{r}0.109^{*} \\
(0.031)\end{array}$ \\
\hline Minority nominee & $\begin{array}{c}0.705 \\
(0.165)\end{array}$ & $\begin{array}{r}-0.349 \\
(0.234)\end{array}$ & $\begin{array}{l}0.750^{* *} \\
(0.096)\end{array}$ & $\begin{array}{l}-0.288^{* *} \\
(0.128)\end{array}$ \\
\hline Female nominee & $\begin{array}{c}1.132 \\
(0.242)\end{array}$ & $\begin{array}{c}0.124 \\
(0.213)\end{array}$ & $\begin{array}{c}0.977 \\
(0.107)\end{array}$ & $\begin{array}{c}-0.024 \\
(0.110)\end{array}$ \\
\hline Renomination & $\begin{array}{l}1.236 \\
(0.436)\end{array}$ & $\begin{array}{c}0.212 \\
(0.353)\end{array}$ & $\begin{array}{l}0.613^{* *} \\
(0.148)\end{array}$ & $\begin{array}{c}-0.489^{* *} \\
(0.241)\end{array}$ \\
\hline Presidential year & $\begin{array}{r}0.576^{*} \\
(0.060)\end{array}$ & $\begin{array}{c}-0.551^{*} \\
(0.104)\end{array}$ & $\begin{array}{r}0.714^{*} \\
(0.046)\end{array}$ & $\begin{array}{c}-0.337^{*} \\
(0.065)\end{array}$ \\
\hline $2^{\text {nd }}$ term president & $\begin{array}{r}0.329^{*} \\
(0.075)\end{array}$ & $\begin{array}{c}-1.110^{*} \\
(0.228)\end{array}$ & $\begin{array}{r}0.420^{*} \\
(0.047)\end{array}$ & $\begin{array}{r}-0.867^{*} \\
(0.112)\end{array}$ \\
\hline $\begin{array}{l}\text { Proportion of Judiciary Committee } \\
\text { members of non-presidential party }\end{array}$ & $\begin{array}{l}1.108 \\
(2.213)\end{array}$ & $\begin{array}{c}0.102 \\
(1.998)\end{array}$ & $\begin{array}{r}0.003^{*} \\
(0.004)\end{array}$ & $\begin{array}{c}-5.965^{*} \\
(1.443)\end{array}$ \\
\hline $\begin{array}{l}\text { Number of pending judicial } \\
\text { nominations }\end{array}$ & $\begin{array}{c}1.000 \\
(0.005)\end{array}$ & $\begin{array}{c}0.000 \\
(0.005)\end{array}$ & $\begin{array}{c}0.995 \\
(0.004)\end{array}$ & $\begin{array}{c}-0.005 \\
(0.004)\end{array}$ \\
\hline $\begin{array}{l}\text { Midterm election under unified } \\
\text { government }\end{array}$ & $\begin{array}{l}1.178 \\
(0.278)\end{array}$ & $\begin{array}{c}0.164 \\
(0.236)\end{array}$ & $\begin{array}{c}0.834 \\
(0.125)\end{array}$ & $\begin{array}{c}-0.181 \\
(0.150)\end{array}$ \\
\hline Post-Bork nomination & $\begin{array}{c}0.139^{*} \\
(0.042)\end{array}$ & $\begin{array}{c}-1.971^{*} \\
(0.303)\end{array}$ & $\begin{array}{c}0.801 \\
(0.182)\end{array}$ & $\begin{array}{c}-0.222 \\
(0.227)\end{array}$ \\
\hline Presidential approval & $\begin{array}{c}1.015 \\
(0.013)\end{array}$ & $\begin{array}{c}0.015 \\
(0.012)\end{array}$ & $\begin{array}{l}1.011^{* * *} \\
(0.006)\end{array}$ & $\begin{array}{l}0.011^{* * * *} \\
(0.006)\end{array}$ \\
\hline Month & $\begin{array}{c}1.093 * \\
(0.022)\end{array}$ & $\begin{array}{r}0.088^{*} \\
(0.021)\end{array}$ & $\begin{array}{c}1.049^{*} \\
(0.014)\end{array}$ & $\begin{array}{c}0.047^{*} \\
(0.013)\end{array}$ \\
\hline \multicolumn{5}{|l|}{ Unit effects } \\
\hline Reagan & - & - & $\begin{array}{c}2.740^{*} \\
(0.423)\end{array}$ & $\begin{array}{l}1.008^{*} \\
(0.154)\end{array}$ \\
\hline Constant & - & $\begin{array}{c}-7.035^{*} \\
(1.180)\end{array}$ & & $\begin{array}{c}-4.651^{*} \\
(0.602)\end{array}$ \\
\hline$p$ & \multicolumn{2}{|c|}{$\begin{array}{c}1.620 \\
(0.080)\end{array}$} & \multicolumn{2}{|c|}{$\begin{array}{c}1.674 \\
(0.062)\end{array}$} \\
\hline $\mathrm{N}$ & \multicolumn{2}{|c|}{280} & \multicolumn{2}{|c|}{1026} \\
\hline Failures & \multicolumn{2}{|c|}{232} & \multicolumn{2}{|c|}{887} \\
\hline LL & \multicolumn{2}{|c|}{-295.105} & \multicolumn{2}{|c|}{-1013.363} \\
\hline
\end{tabular}

${ }^{*} p<0.01,{ }^{* *} p<0.05,{ }^{* * *} p<0.10$

Note: Numbers in parentheses are robust standard errors.

cast it. Under the alternative naive assumption of apolitical or supportive congressional reaction to a nomination, variance in duration would be random. If the politics of lower court nomination is played out mainly in terms of delay 
FIGURE 4

ABA Rating and Confirmation Duration

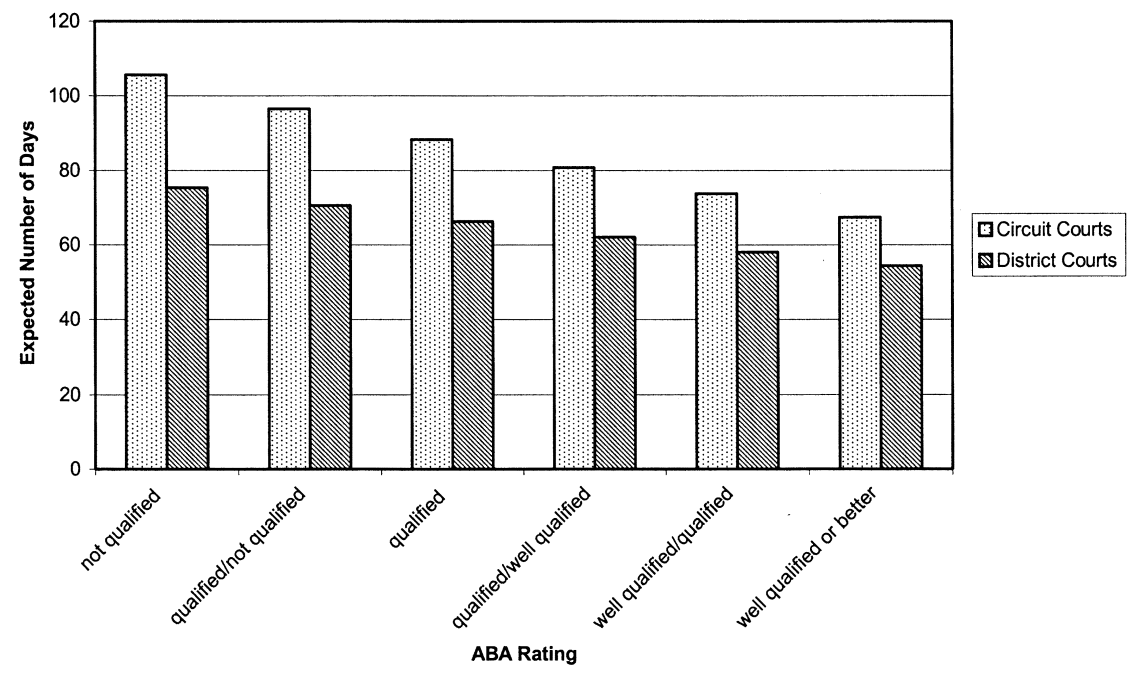

rather than denial, however, then a regime that fosters delay will nonetheless still confirm almost all nominees. Put more directly, if there is more delay, but nominees still are overwhelmingly confirmed, there will be a positive relationship between duration and confirmation.

As was the case in our logit estimations, we find that ABA rating matters for both appeals court and district court nominations. In particular, as the ABA rating of the nominee increases, the length of time required for processing in the Senate decreases, as Figure 4 illustrates. Of special interest is the fact that race and gender manifest no effect on confirmation duration except in the case of minority nominations to the district courts: nominations of minorities to district court vacancies are likely to decrease the hazard rate at which confirmation occurs, thereby increasing the length of time it takes the Senate to process such nominations. ${ }^{25}$ Setting all other variables at their mean values, the expected confirmation duration for nonminority nominees is 59 days while for minority nominees it is 69 days. In addition, renominations are also likely to take longer to wend their way through the Senate, as are those made in later

\footnotetext{
${ }^{25} \mathrm{We}$ considered the possibility that minority status mattered indirectly, rather than directly, through its interaction with divided government. However, when we estimated a model including the interaction of divided government and minority status, the variable could be considered significant only for appeals court nominations using a 0.1 level of statistical significance and not significant by any stretch for district court nominations.
} 
FIGURE 5

Presidential Year and Term and Confirmation Duration

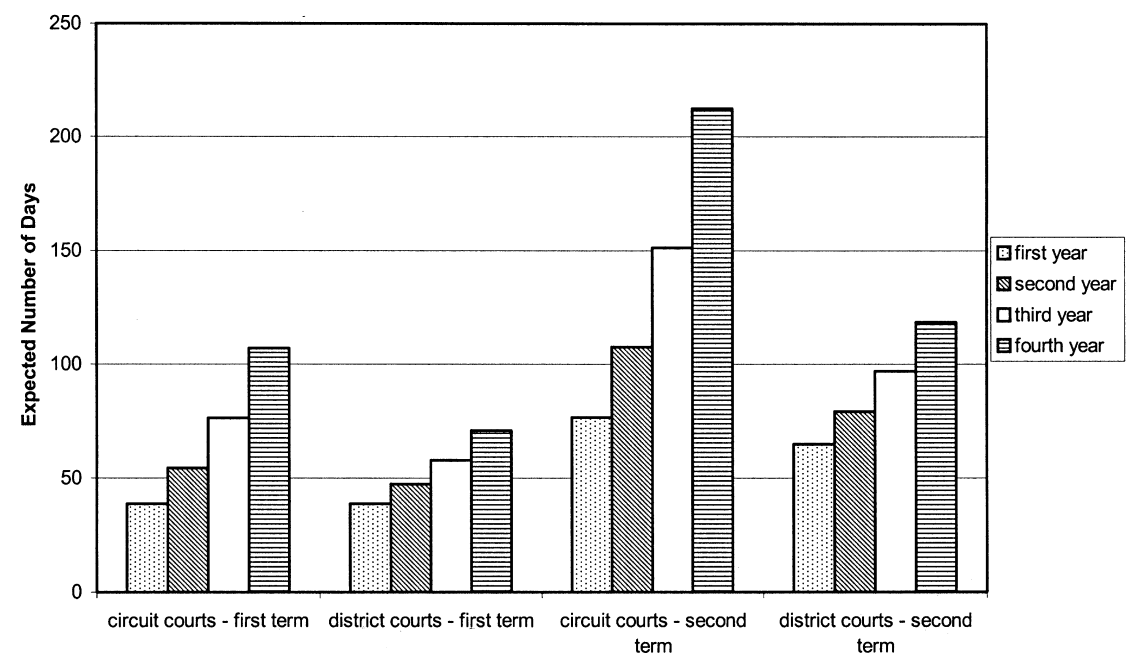

years of a presidential term and by second-term presidents. Figure 5 depicts the latter relationship and clearly indicates that the most disadvantaged nominations are those made to fill appeals court vacancies by second-term presidents serving in their final year of office.

There is little overlap in the pattern of effects for the remaining variables in the appeals court and district court models. For nominations to the appeals courts, the only other explanatory factor to exert an effect is whether or not the nomination postdates the Bork debacle. Those appeals court nominations do require substantially longer processing times. Specifically, nominations to the appeals courts prior to the Bork nomination have an average confirmation duration of 42 days, but that average more than triples to 143 days for those that postdate Bork, ceteris paribus. While in neither case does the number of pending judicial nominations or midterm elections under unified senatorial and presidential control make a difference, nominations for a district court vacancy do take longer as the Judiciary Committee's membership becomes increasingly dominated by non-presidential party senators. Further, presidential approval does not affect appeals court confirmation duration, but it does decrease district court confirmation duration, albeit only at the 0.10 level of significance.

Our analysis is supportive of the hypothesis regarding the timing of nominations and its effect on the time from nomination to confirmation, but only for district court nominations. District court nominations submitted later in the congressional term do experience shorter processing times in the Senate. We are 
cautious in our interpretation of this empirical result, however, since nominations made later in the congressional term by definition have shorter potential durations. Neither a nomination submitted in the sixth month of the first session nor one submitted in the second month of the second session can have a duration that extends beyond the end of the second session. While our a priori reasoning may be correct and the observed result a function of less time available for presidential opponents to turn up unsavory things about a nominee, it is also possible that timing is merely controlling for the theoretical limit of a duration given when it is introduced. Regardless, inclusion of this variable at the very least ensures that the effects of the other variables are not biased due to misspecification.

We think that the differences between the results for the trial courts and the intermediate appellate courts are largely attributable to two factors. First, as noted above, these are quite different institutions in some important ways. Seats on circuit courts of appeals simply matter more in terms of policy making and, thus, are subject to greater scrutiny. Second, there are unavoidable limitations in the data. There are many fewer seats on - and correspondingly, fewer nominations to - the circuit courts. Some of the differences in results are almost certainly due to the much smaller number of observations for the appellate courts. This is likely confounded with other variables that are heavily skewed (e.g., minority nominees).

\section{Conclusion}

Court watchers have become increasingly concerned over what is characterized as a crisis in staffing the federal bench. Numerous groups and organizations, including the American Bar Association and the Miller Center Commission on the Selection of Federal Judges, have examined and reexamined the process and call on all participants to exercise due diligence in fulfilling their respective roles to reduce delay in filling vacancies. Congressional critics have been especially reproachful of ideologically driven opposition to presidential nominees. Senators, on the other hand, maintain they have processed judicial nominations in a timely manner and place the onus for delay on the president. While we do not address presidential activity in this article, we do have evidence that delay on the part of the Senate has increased. As is evidenced by Figure 3, the beginning of the increase corresponds to the $100^{\text {th }}$ Congress and, while the trend has been uneven, increased processing of lower federal court nominations has been consistent since then, jumping considerably in the $105^{\text {th }}$ Congress.

The process of staffing the lower federal court bench is clearly more than a mere administrative obligation imposed on the president and the Senate by the Constitution. Both the president and senators are aware of the consequential nature of the decisions rendered by these courts. The high rate of confirmation, however, scarcely suggests the potential for controversy and interbranch power struggles. But multivariate analysis of the likelihood of confirmation offers ev- 
idence that even in the face of a presumption in favor of confirmation, political forces are at work. Most notably, shifts in the partisan composition of the Judiciary Committee away from the presidential party do not bode well for presidential nominees, at least for those to the district court. Looking beyond outcome to investigate the confirmation process, we have found even greater support for a political model of confirmation politics. Again, divided government is closely associated with increased delay for district court nominations, which a president's approval rating can ameliorate to a limited extent. Coupling this with our finding of increasing delay since the failed Bork nomination provides evidence of the increasing politicization of the process asserted in the popular press and identified previously in the academic literature.

Our results are perhaps most interesting in what they tell us about the characteristics of nominees and the likelihood of favorable senatorial treatment. Both critics and supporters of the process should be heartened to see that the qualifications of a nominee do make a difference, at least to the extent that ABA ratings measure nominee quality. Likewise, the fact that we found no support for either gender or race as influential in the likelihood of confirmation should be cause for relief. What remains troubling, however, is the fact that race does affect the length of time the Senate takes to process a nomination to the federal district courts. Controlling for nominee characteristics, institutional conditions, and political factors, nominations of minorities to the federal district court bench still take longer to process than those of nonminorities. Undoubtedly, presidents engage in strategic nomination behavior and are cognizant of the senatorial realities they face in getting their nominations confirmed. Thus, it is quite likely that in selecting minority and female nominees, a president may settle on those individuals who are least likely to raise additional red flags in the Senate. In fact, there is at least some evidence that this was the case during the Clinton administration. ${ }^{26}$ We suggest that it is at least possible that the results we present here with regard to the race and gender of nominees may underestimate the effect of these characteristics on senatorial processing due to a presidential selection effect.

Federal district courts and circuit courts of appeal have on their benches hundreds of judges making thousands of decisions each year, affecting the lives and fortunes of litigants and making policy for the country more broadly. The constitutional process through which these judges ascend to the bench requires the joint effort of the president and the Senate. Small wonder, then, that we should find the outcome and process of lower federal court confirmation influenced by both the political context and the nature of the institutions involved. The same can be said for staffing the lower federal court bench as has been demonstrated for staffing the U.S. Supreme Court: the process is political.

\footnotetext{
${ }^{26}$ Warren Richey, "Clinton Remaking Reagan Bench," Christian Science Monitor, 17 February 1999.
} 


\section{Appendix}

\section{Variable Coding}

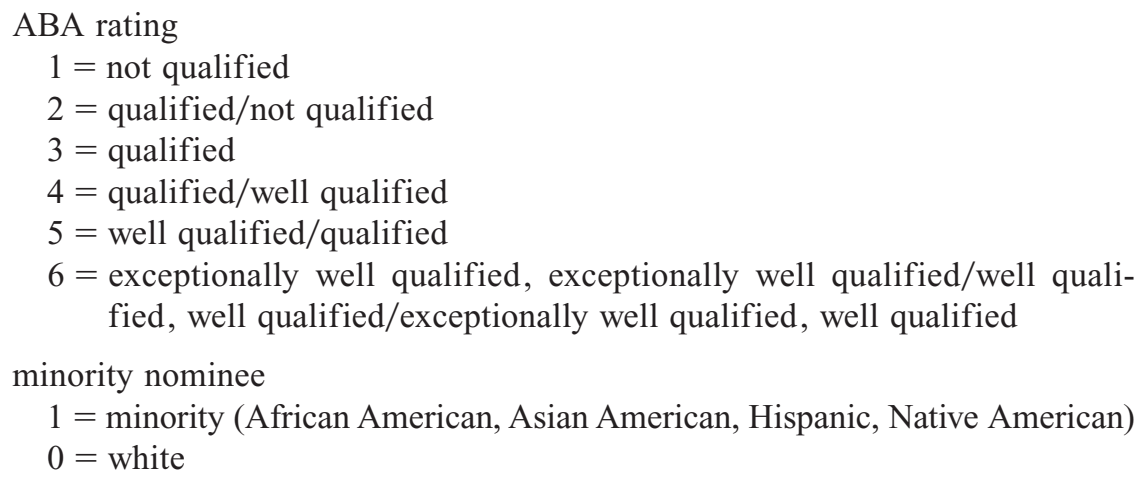

female nominee

$1=$ female

$0=$ male

renomination

$1=$ nominee previously nominated for same vacancy but was unsuccessful

$0=$ nominee not previously nominated for same vacancy

presidential year

$1=$ nomination made by president in first year of term

$2=$ nomination made by president in second year of term

$3=$ nomination made by president in third year of term

$4=$ nomination made by president in fourth year of term

$2^{\text {nd }}$ term president

$1=$ nomination made in president's second term in office

$0=$ nomination made in president's first term of office

Judiciary Committee Composition

proportion of Judiciary Committee of non-presidential party

pending nominations

number of nominations to be processed by Senate at time of nomination

unified government in midterm election year

$1=$ nomination made in midterm election year when presidency and Senate controlled by same party

$0=$ nomination not made in midterm election year when presidency and Senate controlled by same party

post-Bork

$1=$ nomination made after the Bork nomination

$0=$ nomination made before the Bork nomination 
presidential approval

presidential approval rating, ranging from 0 (no approval) to 1 (highest approval)

timing

$$
\begin{gathered}
1=\text { nomination made in January of } 1^{\text {st }} \text { session of congressional term } \\
: \text { : } \\
\begin{array}{c}
13 \\
\text { nomination made in January of } 2^{\text {nd }}
\end{array} \text { session of congressional term } \\
: \\
24=\text { nomination made in December of } 2^{\text {nd }} \text { session of congressional term }
\end{gathered}
$$

Manuscript submitted 13 April 2000

Final manuscript received 2 April 2001

\section{References}

Abraham, Henry J. 1992. Justices and Presidents. New York: Oxford University Press.

Aldrich, John H., and Forrest D. Nelson. 1984. Linear Probability, Logit, and Probit Models. Beverly Hills, CA: Sage.

Allison, Garland W. 1996. "Delay in the Senate Confirmation of Federal Judicial Nominees." Judicature 80(1): 8-15.

Barrow, Deborah J., Gary Zuk, and Gerald Gryski. 1996. The Federal Judiciary and Institutional Change. Ann Arbor: University of Michigan Press.

Blossfeld, Hans-Peter, Alfred Hamerle, Karl Ulrich Mayer. 1989. Event History Analysis. Hillsdale, NJ: Lawrence Erlbaum Associates.

Bond, Jon R., and Richard Fleisher. 1990. The President in the Legislative Arena. Chicago: University of Chicago Press.

Box-Steffensmeier, Janet M., and Bradford S. Jones. 1997. "Time Is of the Essence: Event History Models in Political Science." American Journal of Political Science 41(4): 1414-61.

Bronner, Ethan. 1989. Battle for Justice: How the Bork Nomination Shook America. New York: W. W. Norton.

Caldeira, Gregory A., and John R. Wright. 1998. "Lobbying for Justice: Organized Interests, Supreme Court Nominations, and the United States Senate." American Journal of Political Science 42(2): 499-523.

Cameron, Charles M., Albert D. Cover, and Jeffrey A. Segal. 1990. "Senate Voting on Supreme Court Nominees: A Neoinstitutional Model." American Political Science Review 84(2): 525-34.

Cameron, Charles M., and Jeffrey A. Segal. 1999. "The Politics of Scandals: The Case of Supreme Court Nominations, 1877-1994." Paper presented at the 1999 Midwest Political Science Association Meeting, Chicago.

Chase, Harold W. 1972. Federal Judges. Minneapolis: University of Minnesota Press.

Goldman, Sheldon. 1966. "Voting Behavior on the United States Courts of Appeals, 1961-1964." American Political Science Review 60(2): 374-83.

Goldman, Sheldon. 1993. "Bush's Judicial Legacy: The Final Imprint.” Judicature 76(6): $282-97$.

Goldman, Sheldon. 1995. "Judicial Selection under Clinton: A Midterm Examination.” Judicature 78(6): 276-91.

Goldman, Sheldon. 1997. Picking Federal Court Judges: Lower Court Selection from Roosevelt through Reagan. New Haven, CT: Yale University Press.

Gottschall, Jon. 1983. “Carter's Judicial Appointments: The Influence of Affirmative Action and Merit Selection on Voting on the U.S. Courts of Appeals." Judicature 67(4): 164-73.

Guliuzza Frank, III, Daniel J. Reagan, and David M. Barrett. 1994. "The Senate Judiciary Committee and Supreme Court Nominees: Measuring the Dynamics of Confirmation Criteria." Journal of Politics 56(3): 773-87. 
Hartley, Roger E., and Lisa M. Holmes. 1997. "Increasing Senate Scrutiny of Lower Federal Court Nominees.” Judicature 80(6): 274-78.

Holmes, Lisa M., and Roger E. Hartley. 1998. "The Changing Roles of Political and Institutional Factors in Judicial Confirmation Hearings from 1969 to 1996." Paper presented at the 1998 American Political Science Association Meeting, Boston.

McFeeley, Neil D. 1987. Appointment of Judges. Austin: University of Texas Press.

Moraski, Bryon J., and Charles R. Shipan. 1999. "The Politics of Supreme Court Nominations: A Theory of Institutional Constraints and Choices." American Journal of Political Science 43(4): 1069-95.

Ruckman, P.S., Jr., 1993. "The Supreme Court, Critical Nominations, and the Senate Confirmation Process.” Journal of Politics 55(3): 793-805.

Segal, Jeffrey. 1987. "Senate Confirmation of Supreme Court Justices: Partisan and Institutional Politics.” Journal of Politics 49(4): 998-1015.

Slotnick, Elliot E. 1988. "Federal Judicial Recruitment and Selection Research: A Review Essay." Judicature 71(6): 317-24.

Wendy Martinek is assistant professor of political science, State University of New York at Binghamton, Binghamton, NY 13902-6000.

Mark Kemper is assistant professor of political science, Bridgewater State College, Bridgewater, MA 02325.

Steven R. Van Winkle is assistant professor of political science, Syracuse University, Syracuse, NY 13244-1020. 